\title{
Metapopulations OF MONTANE AND LONG-TAILED VOLES (Microtus montanus and M. longicaudus), AND HaNTAVIRUS AND Plague IN THE JACKSON Hole SMALl MAMMAl COMMUNITY
}

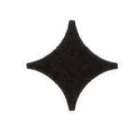

\author{
FREDERICK J. JANNETT, JR. $\downarrow$ DEPARTMENT OF BIOLOGY, \\ SCIENCE MUSEUM OF MINNESOTA \\ DEPARTMENT OF FISHERIES AND WILDLIFE \\ UNIVERSITY OF MINNESOTA $\uparrow$ ST. PAUL
}

\section{$\downarrow$ OBJECTIVES}

The purpose of the long-term research begun in 1971 on metapopulations of voles is to enumerate patterns in survivorship, reproduction, and morphology across the sections of the metapopulations. The study sites for Microtus montanus were chosen to represent primary and secondary habitat, and proximate and isolated habitat patches.

The purpose of the research on hantavirus begun in 1994 is to ascertain the extent of hantavirus among as many species of small mammals as possible, to identify the strain(s), to understand the presence of hantavirus across species and among the metapopulations of voles, and to assess the potential for human contact. The purpose of the research on plague begun in 1995 is to test the long-standing hypothesis that voles are a reservoir in the intervals between plague outbreaks among ground squirrels.

\section{$\downarrow$ METHODS}

Most trapping periods were limited to two days so that impact on the respective populations would be minimized. From fresh specimens of voles, eyes were removed for age determination upon lens weight (Gourley and Jannett, 1975).

In October, 1997 we undertook standard monitoring efforts at nine known populations of Microtus montanus and at two of $M$. longicaudus for long-term metapopulation data; an unstructured sample was made of one other known $M$. montanus population.

Specimens were secured for the hantavirus and plague surveys in the 10 long-term study populations of Microtus montanus and two long-term study populations $M$. longicaudus. They were also secured at 14 additional sites ranging as far south as Moose and as far north as meadows northwest of Flagg Ranch in the Rockefeller Memorial Parkway. Collections were made in and/or around buildings at 10 sites, including Beaver Creek, Moose, Colter Bay, and the Research Station at AMK Ranch. Additional collecting sites were proximate to human habitation at Flagg Ranch, Elk Ranch, and the Moran grade school. Fleas were removed from most specimens and saved for identification and plague culture by Dr. Ken Gage of the Centers for Disease Control and Prevention (CDC), Ft. Collins, Colorado. For the hantavirus survey, specimens were sacrificed with anesthetic. Blood and lungs were removed and 
frozen, and the blood was shipped to CDC, Atlanta, where it was examined for hantavirus using ELISA. Blood was saved on Nabuto strips to test for plague at CDC, Ft. Collins.

\section{$\downarrow \quad$ ReSUlts}

\section{DEMOGRAPHY OF MICROTUS.}

In the 10 populations of Microtus montanus monitored in October, 1996 and again in October, 1997, there were generally more voles in 1997 than in 1996. In two samples there were no $M$. montanus and in the eight other samples the numbers of specimens ranged from four to only 52 . Numbers of voles showed disparate changes. Two sites yielded no specimen in either year. One site had no change in numbers. Numbers increased at four sites by $10 \%, 53 \%, 425 \%$, and $1000 \%$, respectively. Numbers decreased at three sites by $55 \%, 67 \%$, and $80 \%$, respectively. There was a pattern in change of numbers of voles among sites with primary habitat, peripheral to primary habitat, or with secondary habitat. Three of the four sites with increasing vole numbers were among the four sites with primary habitat for this species.

Fall breeding by Microtus montanus was evidenced by lactating and recently lactating females, but only one obviously pregnant female. Of the 10 sites monitored for $M$. montanus where voles were obtained in October, 1997, one or more parous females were secured at each of six sites, and each of these sites had at least one female recently or still lactating. Each of the sites where $M$. longicaudus predominate over $M$. montanus had a parous $M$. montanus in the respective sample. Among the eight sites with parous female(s), the operational sex ratios (OSR) (males:females) of reproductively active and recently active male voles to parous females ranged from $1: 1$ to only $1: 1.5$. The percentage of females still reproductively active in the eight sites with parous female(s) ranged from $50 \%$ to $100 \%$, and averaged $90.6 \%$. In addition, there were three other parous females at other sites sampled in October for the hantavirus survey; each was lactating or recently lactating.

Numbers of Microtus longicaudus were characteristically low at the two monitored sites with primary habitat for this species. However, considering all seven sites where this species was found in 1996, numbers declined at six sites in 1997.
As is usual for this species in northern Jackson Hole in October, breeding had ceased.

\section{HANTAVIRUS AND PLAGUE.}

For hantavirus, blood was examined serologically from 304 specimens in May and 584 specimens in October. The survey included 12 rodent species, one species of weasel, and at least two species of shrews (Table 1). The efficacy of the ELISA test for hantavirus in carnivores and shrews is problematic. Three species tested positive for hantavirus in 1997 as in previous years: Peromyscus maniculatus, Microtus montanus, and $M$. pennsylvanicus. In addition, one Tamias amoenus tested positive in October, 1997.

Table 1. Species, sample sizes, and occurrences of hantavirus upon serology in 1997.

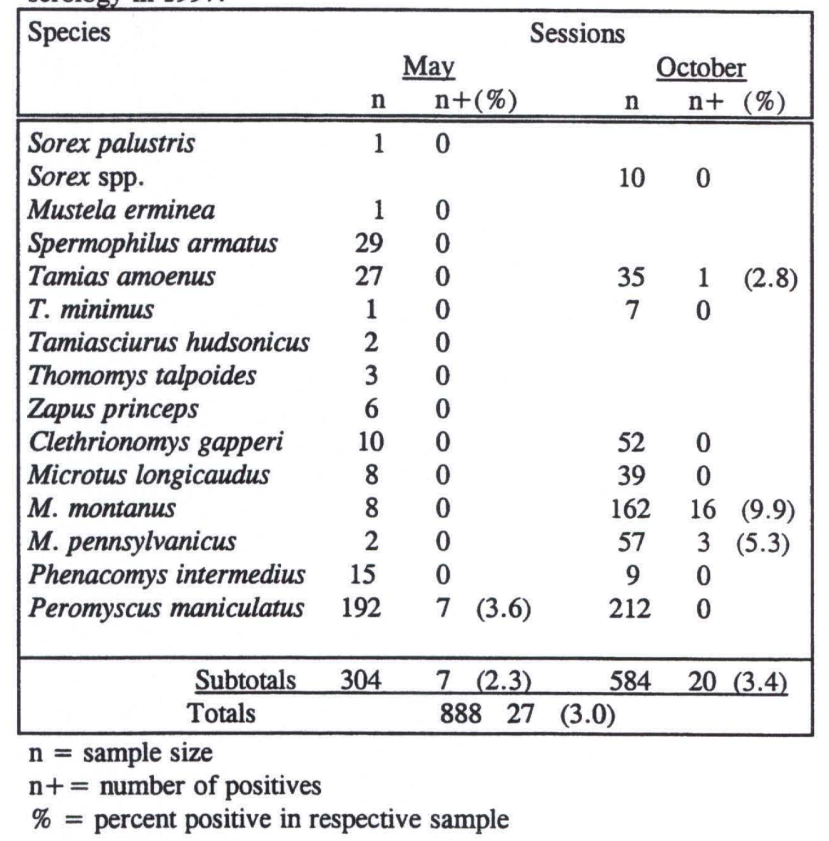

In May, seven of 192 (3.6\%) deermice (Peromyscus maniculatus) were positive. Specimens which tested positive were all secured in and around human habitation at four disparate locations (Table 2). The incidence per site ranged from $2.7 \%$ to $9.5 \%$, the highest being at Moose. No other species tested positive in May.

In October, no specimen of Peromyscus maniculatus tested positive. Sixteen of 162 (9.9\%) Microtus montanus and three of 57 (5.3\%) M. pennsylvanicus tested positive. The one yellow-pine 
chipmunk (Tamias amoenus) which tested positive represented an incidence of $2.8 \%$ for that species.

Table 2. Numbers of Peromyscus maniculatus and the incidence of hantavirus in July (1995 and 1996) and May (1997) at sites with buildings.

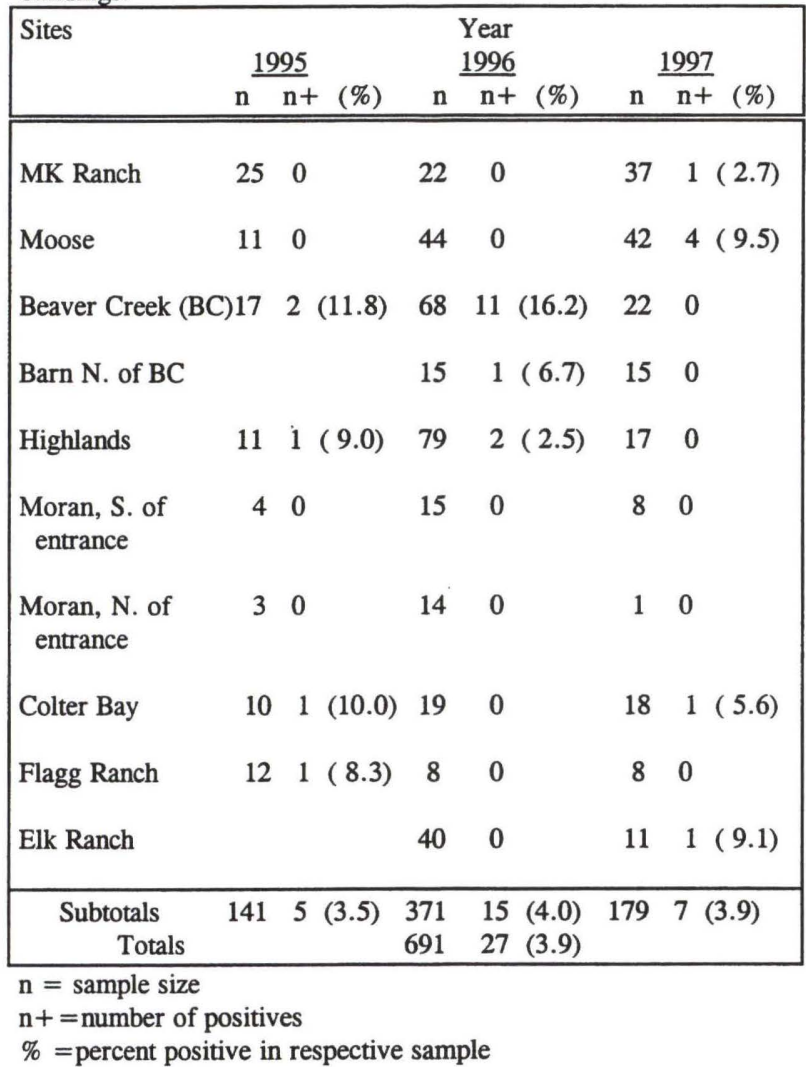

Of the seven specimens of Peromyscus maniculatus which tested positive for hantavirus, six were parous adults, each lactating and/or pregnant; the remaining individual was also an over-wintered female. Of the 19 specimens of Microtus spp. which tested positive, 15 (79\%) were adults; all four subadults which tested positive were from the same site.

None of the specimens of Microtus spp. or Tamias amoenus which tested positive were secured in or around buildings. All but one of them were secured in primary habitat for the respective species. The remaining $M$. montanus which tested positive was secured in an isolated habitat patch contiguous to an open field (primary habitat) where one or more positive specimens were obtained in 1997 and in previous years.

Tests for plague in 1997 have not yet been reported by CDC.

\section{DISCUSSION}

The numbers of Microtus montanus generally increased in 1997 above numbers found in 1996, especially in open field primary habitat. Breeding rates were high in 1997. This correlation of increasing fall breeding and increasing population numbers is typical of microtine rodents (Krebs and Myers, 1974). There was additional support in 1997 for the correlation of continued fall breeding with operational sex ratios characterized by a relatively large number of adult males, a pattern conducive to social maintenance of breeding (Jannett, 1984a, 1984b).

The finding of Peromyscus maniculatus testing positive for hantavirus was significant. This species is the primary reservoir for the Sin Nombre (SNV) strain of hantavirus in the western United States (Childs et al., 1994). The strain present in the Jackson Hole specimens is currently assumed to be SNV (S.T. Nichol, personal communication), of considerable significance to human health. The incidence of $P$. maniculatus testing positive for hantavirus was low in the total sample. However, the positive specimens were widely distributed and all were near or in human habitation. Three sites with buildings were added to the list of those where specimens testing positive have been found: AMK Ranch, Elk Ranch, and Moose.

In 1997, all Peromyscus maniculatus and most Microtus spp. positive for hantavirus were adults. This profile supports the emerging pattern that there is a higher incidence among adults (Douglass et al. 1996; this study, 1994-1997).

It had been hypothesized that a higher incidence of positive Peromyscus maniculatus would be found in May than in July in previous years, because a greater proportion of the specimens in May would be adults and adults are more likely to be positive. This was not apparently the case. Although not all specimens have been examined and coded for age and reproductive condition, most specimens in May, 1997 were indeed adults. But the overall percentage of positive specimens $(3.6 \%)$ in May was comparable to the percentage of positive specimens in July, 1995 (3.1\%) and 1996 (3.6\%). Among just peridomestic specimens, the respective percentages were $3.9 \%, 3.5 \%$, and $4.0 \%$. 
Again in 1997, there were distinct patterns of foci for the occurrence of hantavirus among voles, both Microtus montanus and M. pennsylvanicus. All specimens which tested positive in 1997 came from only five sites. Four of these sites yielded positive specimens in previous years. The new site was contiguous to one of the others. With the exception of this one new site, all sites with positive Microtus spp. were primary habitat for the respective species.

Specimens are currently being analyzed for age and reproductive condition. However, the following patterns are emerging:

1. Overall incidence in all three species in October, 1994-1997 has been relatively stable

(Peromyscus maniculatus: 0\%, 0\%, 0.9\%, 0\%;

Microtus montanus: $1.4 \%, 1.4 \%, 6.3 \%, 9.9 \%$;

M. pennsylvanicus: 5.6\%, 2.6\%, 18.4\%, 5.3\%).

2. Overall incidence in Peromyscus maniculatus in July (1995 and 1996) and May (1997) has been stable (3.1\%, 3.6\%; 3.6\%). (Sample numbers of Microtus spp. in May, 1997 were very small.)

3. For Peromyscus maniculatus and both species of voles, most positive specimens have been adults.

4. For Peromyscus maniculatus, all positive specimens (1994-1997) except one have been secured in and around buildings.

5. Most positive voles (Microtus montanus and $M$. pennsylvanicus) have been secured in the respective primary habitat for the two species.

Maintenance of the strict trapping protocols in this research would allow us to elucidate patterns over time, space, and variations in population numbers.

\section{SPECIMEN DEPOSITION}

Science Museum of Minnesota. Lung tissues are in the frozen tissue collection of the Bell Museum of Natural History, St. Paul.

\section{ACKNOWLEDGMENTS}

I thank Grand Teton National Park for permission to work in the Park and for in-kind staff support, and the University of Wyoming-National Park Service Research Center for its hospitality and the use of traps. I also thank Grand Teton National Park for a grant in aid of this research and Robert Schiller for his continued interest. This work was also supported by the Science Museum of Minnesota and the Centers for Disease Control and Prevention. I thank Neil J. Vanderbosch for assistance in the field, and Renee Leshan (NPS) for collecting specimens.

\section{LITERATURE CITED}

Childs, J. E., T. G. Ksiazek, C. F. Spiropoulou, J. W. Krebs, S. Morzunov, G. O. Maupin, K. L. Gage, P. E. Rollin, J. Sarisky, R. E. Enscore, J. K. Frey, C. J. Peters, and S. T. Nichol. 1994. Serologic and genetic identification of Peromyscus maniculatus as the primary rodent reservoir for a new hantavirus in the southwestern United States. J. Infec. Dis., 169: 1271-1280.

Douglass, R. J., R. Van Horn, K. W. Coffin, and S. N. Zanto. 1996. Hantavirus in Montana deer mouse populations: preliminary results. J. Wildl. Dis., 32: 527-530.

Gourley, R. S. and F. J. Jannett, Jr. 1975. Pine and montane vole age estimates from eye lens weights. J. Wildl. Manage., 39: 550-556.

Jannett, F. J., Jr. 1984a. Reproduction of the montane vole, Microtus montanus, in subnivean populations. Special Publ. Carnegie Mus. Nat. Hist., 10: 215-224.

Jannett, F. J., Jr. 1984b. Sex ratios and late fall breeding in the montane vole, Microtus montanus. Amer. Zool., 24: 3A.

Krebs, C. J. and J. H. Myers. 1974. Population cycles in small mammals. Adv. Ecol. Res., 8:267-399. 